\title{
THE BEGININGS OF SKILLED TRADE ENTERPRISE IN THE CZECH LANDS
}

Prof. PhDr. Jana Geršlová, CSc.

Ekonomická fakulta VŠB-TU Ostrava, Sokolská 33, 70121 Ostrava, jana.gerslova@vsb.cz

\begin{abstract}
Development of free enterprise in the middle of the $19^{\text {th }}$ century, which was based on capital relations in the sphere of both production and market, was incompatible with the old system of guild craft and its complicated regulations. The Law of the Trade Code from 1859 abolished all measures that had been in effect until then and introduced trade freedom within the new economic policy and the needs of modern enterprise. According to the law, all citizens had theoretically the access to all craft trades after paying the set taxes - this resulted in a huge wave of trades being set up. Freedom of production as well as sales was proclaimed. Commercial Code from 1862, by which the absolute free competitiveness in business ventures had been legalized, became an organic amendment to the Trade Code from 1859. The article deals with the concepts of trade, a practice of its gaining or losing, it pays attention to a number of amendments. Trade legislation was connected with commercial activity and its conditions. An important role in the support of commercial activities was played by trade and commercial associations - the article describes their long history from their formation in 1850 up to their dissolution in 1948. Working of firms in the branch of industry, commerce and craft trades was strongly influenced by licensing authorities that directly permitted or refused trade licenses. The last chapter focuses on the Law against unfair competition from 1927 that was passed as the important reaction to business practice.
\end{abstract}

Key words: History of enterprise, trade legislation, commercial legislation, economic history of the 19th and 20th century

JEL Classification: H83; N43; N44

DOI: $10.2478 / \mathrm{v} 10135-011-0007-\mathrm{x}$ 


\section{THE BEGININGS OF SKILLED TRADE ENTERPRISE IN THE CZECH LANDS ${ }^{1}$}

\section{Jana Geršlová ${ }^{2}$}

\section{Introduction}

The economy of the Czech lands in the Austro-Hungarian monarchy was relatively well developed, and in a number of branches, especially in the light industry, the Czech lands achieved excellent results. The second half of the $19^{\text {th }}$ century was also the period in which the society was changing. After the abolition of serfdom and other duties, economic positions of the nobility were weakened and a new social stratum appeared in the society - the active skilled trader. The development of free enterprise in the middle of the $19^{\text {th }}$ century based on capital-type relationships in the sphere of both production and market was incompatible with the old system of guild craft and its complex regulations. On one hand, they were to protect the existence and functions of guild production, on the other hand, however, they hindered possibilities of master craftsmen' economic activities by tens of provisions that in fact did not allow them to 'step out from the line' and to follow the path of economic competition. Even a new type of enterprise declaring support to business liberalism could not be put into practice without working out certain collectively binding rules that should prevent liberalism from turning into anarchism with its destructive consequences. ${ }^{3}$

\section{Skilled Trades Legislation}

In the Austro-Hungarian monarchy, an idea arose in that historical situation aimed at accepting a complex of principles and rules by which the enterprise should be managed. According to the bill worked out by K. L. von Brucken, the Minister of Finance, the Law of Trade Code was passed on December 20, 1859. In principle, it cancelled all measures that had been in force in that branch to that time and introduced trade freedom within the new economic policy and the needs of modern enterprise. According to that Law, all citizens theoretically had the right of access to all trades after paying a set tax. Freedom of both production and sales was proclaimed. Commercial Code issued in

\footnotetext{
${ }^{1}$ The article was created with the financial support of CR Grant Agency (GAČR) within the project no 409/08/1139 under the title The Modern History of Entrepreneurship and Entrepreneurs in Europe in the Second Half of the $19^{\text {th }}$ Century and in the First Half of the $20^{\text {th }}$ Century. The article extents and adapts three previous papers of the author for the Public Administration Journal '99, no. 5, 28 and 42, 1999.

${ }^{2}$ Prof. PhDr. Jana Geršlová, CSc., Ekonomická fakulta VŠB-TU Ostrava, Sokolská 33, 70121 Ostrava, jana.gerslova@vsb.cz

${ }^{3}$ The author draws straight from archives from the beginning of the 1990s, that is why the sources are cited according to the names of the archives of that time. More on the topic Brom (2001), Jakubec (2007a), Jakubec (2007b), Jakubec (2007/2008), Jakubec (2008).

${ }^{4}$ By the Law No. 227/1859 Code of Laws, article 1, par. 1-152 in ten chapters and the amendment about work cards. Also in Geršlová, Sekanina (2003).
} 
1862, by which the absolute free competition in trade enterprise had been legalized, became an organic amendment to the Commercial Code from 1859.

The Trade Code underwent a number of changes and amendments in the period of its being in effect. For example the amendment from 1883 - to the then concessions and free trades the third category was added - a so-called category of craft trades can be ranked among the most important ones. To carry on the craft trades, it was not necessary to obtain the explicit concession but the interested person was obliged to submit a certificate of eligibility (a vocational certificate), which had previously happened only in exceptional cases. The law itself did not specify which trades were seen as crafts; such a decision depended on the government. A majority of the most common occupations could be ranked among those production branches (shoemakers, bakers, tailors, carpenters, locksmiths, plumbers, butchers, barbers, glaziers and the like). The list of so-called concession trades was extended and mentioned by their names.

An amendment brought into effect in 1885 modified some issues related to work conditions of workpeople. Issues of apprenticeship were altered by the third amendment to the Trade Code in 1897. In the amendment from 1902, passages concerning business agents and peddling were modified. Especially the amendment to the Trade Code (Regulations) by which a number of craft trades was increased (54 branches altogether); but it was not easy to obtain a card of eligibility as the requirements were increased to a great extent. The validity of the Trade Licensing Office activities was accepted also after the formation of Czechoslovakia. In December 1918, however, one of further interventions was carried out in the form of cutting hours of work to eight even though hours of work had been previously modified.

The concept of a skilled trade was not directly defined by the Trade Licensing Office but the formulation of its characteristic features was sufficiently rich in content. The Trade Licensing Office considered as a skilled trade such enterprise that had to be:

a) Permitted from the objective point of view (it did not have to be inconsistent with morals and laws of the state), permanent (in essence regularly materialized, not only occasionally) and performed for sales (for market, for the third person, not only for own consumption or consumption of one's own family);

b) Independent from the subjective point of view (i.e. based on own invested means, or on the share of invested means) and carried on in order to gain profit (by those aspects the economic motivation of the trade was accomplished, which was its capital substance).

However, some activities were exempted from subordination to the Trade Code. Agricultural farms were developed entirely independently, it was possible to do 'paid labor of the lowest status' beyond the rules of trade activities, e.g. domestic chores, literary activity, and the fine arts. Mining industry, railway traffic, shipping, medicine, pharmacy, organizing of public performances and shows (theaters, cinemas, amusement programs, publishing of periodical press, peddling and the like), and all kinds of state enterprise were liable to special regulations with regard to their distinctive features requiring special readiness as well as special working, safety and other conditions of the profession. 
Attaining a skilled trade authorization had various forms and stages. Somewhere a 'notification', i.e. reporting about the skilled trade and its registering, were sufficient. Somewhere else it was a more complex approval procedure accompanied by a thorough investigation and by setting conditions for opening a business and granting a concession. ${ }^{1}$ Such procedure concerned especially important kinds of enterprise connected with extraordinary demands made on their traders. Granting a concession was in no case a matter of Office volitional act, its arbitrariness; the institution granting a concession was responsible only for 'finding the right', i.e. examining whether or not the applicant met preconditions for enterprise activity, then a decision was made on the basis of those documents.

In addition to the features of enterprise mentioned above, every tradesman had to meet mainly two demands for carrying on a skilled trade - as a citizen he had to be 'unimpeachable' (no previous crimes and criminal acts especially those that might reflect in an unfavorable way in their business practice) and 'professionally qualified', which meant that he had to have proper training and a certain length of experience graded according to professions. ${ }^{2}$

As long as trade enterprise is concerned, it was above all production trades in the field of crafts. In addition to all preconditions of skilled trade existence, the Trade Code also required further duties. It was for example observing valid regulations about opening hours, overtime work, Sundays and public holidays, and about a possible permitting of exceptions, about apprentices' training and work conditions, work safety, protection of employees' health and the like. The Trade Code, however, never encroached upon the scale of production and services, sales, prices, profits, in none of its requirements it limited the space for economic competition, and for regulating functions of market mechanism. It wanted to act as one of instruments of its trouble-free working.

Rules of how the trade license can be lost were set as well. The right to perform a trade expired by death of a trade license holder, by dissolution of the firm, because of person's impeachment or loss of professional competence, revelation of a fraud in applications for granting a trade license, and poor performing a trade. Discrepancy between the reported and actually performed activity, covering of other person's enterprise by own trade license, reporting a trade as factory work which was benefited by a number of regulations, ${ }^{3}$ all that belonged to the most frequent frauds of that kind.

${ }^{1}$ Division into the so-called independent or free trades and craft trades or concession trades were
in question.
${ }^{2}$ A certificate of competence or license required by the amendment worked out in 1907 was a
subject of a number of discussions in the Chambers of Commerce and Trades Associations. For
example, there was a lecture given by Prof. Dr. František Weyer, the chairman of the National
Statistical Office, in 1926 (Chamber of Commerce journal, 1926, No. 12, p. 1-7) which concerned
above all the fears of a possible abuse of granting a certificate within a production monopoly or
some kind of 'numeru clausu' in the field of trade. On one hand, there were representatives of the
opinion that products served as a best control, which was supported by interest communities of
tradesmen (for some crafts the membership was compulsory). They understood it as an attack on
their personal and business liberties. On the other hand, there was a view emphasizing a possible
incompetence of tradesmen, protection of producers against incapable tradesmen and the like.
Those arguments were predominantly associated with the national economic policy.
${ }^{3}$ See the Dictionary of Czechoslovak Public Law, Volume IV, Brno 1938. Entry Trade Law, pp. 


\section{Commercial Legislation}

In the Austro-Hungarian monarchy, legal adjustments were already accepted and the commercial law and relationships resulting from it were always a part of country's legislation for trading and business ventures. This branch was first specified in the General Civil Code. After the formation of independent Czechoslovakia in 1918, the General Commercial Code ${ }^{1}$ was worked out. In the course of changes in the country's economy and requirements for business ventures, additional laws were introduced. It concerned e.g. the Act on Stock Exchanges introduced in 1875, agricultural marketplaces from 1903, and produce exchange, Bratislava, in 1922. The Code specified Commercial enterprise, too. At the same time, there was a central facility in the field of commercial law - registers (with merchants' registered firms, the article of business etc.), banks worked as firms engaged in business in a 'trading way' and exchanges as a 'regular meeting of merchants (traders)' the purpose of which were sales of goods. Commercial Code furthermore defined and specified working of commercial companies and determined conditions in which they were allowed to develop their commercial activities; for example to divide commercial companies into personal, in which the individuality of persons mattered (public, with a limited partnership), and into capital-type companies.

Among them there were joint stock companies consisting of shareholders, limited partnership dealing with shares including shareholders and general partners, and joint stock companies. Commercial code and the field of business law were wide-ranging and it was the interest of every entrepreneur in that field to understand that complicated mechanism.

Legislation relating to skilled trade activities in the branch of industries, production crafts, trade and services in the period of the first Czechoslovak Republic was then built on the previous developmental status and it tried to improve its shape proportionally to the new stages of enterprise. Not always was it able to keep up with the changes of that time, though; some decisions and measures were not thought through from the view of development trends, or they left space for ambiguous interpretations. It was connected with the overall development of influence on the part of state, its authorities and institutions, businessmen and their corporations, employees and their interest organizations, in the last instance then with the final influence of political parties as spokesmen of socially professional groups of population in the parliament and government, and in the sphere of legislative and executive initiatives. This also concerned many other laws and government regulations that influenced fates of enterprises in the 1920s and the 1930s. As a whole, however, a solid base was built up in the legislation for businessmen in the period of the First republic, and it considerably depended on each of them and how they applied the 'rules of the game' in practice.

\section{Commerce and Trade Chambers}

The development of enterprise was very tightly connected with, and also influenced by important institutions of the national economy administration, which were commerce and trade chambers. They had been established already in the period of the monarchy as

907-954.

${ }^{1}$ Rouček (1938). 
advisory institutions in the sphere of Ministry of Commerce activities, first by the law brought into effect in 1850 in and amended in 1868. The form of commerce and trade chambers (hereinafter $\mathrm{CTCH}$ ) organization according to that law remained unchanged till the end of the monarchy and later, without significant changes, it was adopted by Czechoslovakia. ${ }^{1}$ Self-government institutions resided in the whole of the territory - in the period of Czechoslovakia formation there were $11 \mathrm{CTCH}$ with their seats in Prague, Liberec, České Budějovice, Pilsen, Cheb, Brno, Olomouc, Opava, Bratislava, Banská Bystrica and Košice. Commerce and Trade Chambers were established as advisory bodies for the area of all trades, industries and commerce. Sometimes they also worked as authorities of the state administration, especially in case the agenda of that character was explicitly delegated to them - e.g. recording of trademarks and samples, verification of goods origin and confirmation of invoices, and the like. According to the law, ${ }^{2}$ the chambers were supposed to consult commercial and trading matters with the government and particular ministries, and inform them on the needs of commerce and trades. Their task was also to provide expert report on bills concerning industry, commerce and trades before they were submitted to legislative institutions. CTCH also expressed their opinions on the rise of various institutions of economic character, e.g. stock exchanges and public warehouses. Trade authorizations were processed by trade chambers that had a register of formal firms, supervised trade and industrial statistics and ran a very complex agenda of various certificates, formal expert opinions; they also often acted as arbitration courts in disputes in the sphere of industry, business and trades.

The leadership of particular chambers was always elected by all businessmen, industrialists and tradesmen of the relevant district who paid taxes in a set amount. In those chambers, there were three sections - commercial, trading and industrial. In April 1922, the chambers merged and the Central Office of Commercial and Trade Chambers in Prague ${ }^{3}$ came into existence. Commerce and Trade chambers were seen as interest organizations but membership in them was compulsory. A newly established Central Office then became a certain mediator between governmental institutions and chambers. It reported to chambers news, informing them on the new bills, it was represented in central bodies sessions - e.g. also in the National Assembly. It was also supposed to

\footnotetext{
${ }^{1}$ A relatively extensive archive material describing their activities has been well-preserved in our country. It is especially the collection of the central office of commerce and trade chambers (Czech abbreviation - ÚOŽK) 1922-1948, the State Central Archives, Prague.

${ }^{2}$ This development was so complicated that after the formation of Czechoslovakia, it was necessary to unify the legislation of Austrian part of the monarchy ( 8 chambers in the Czech lands) with Hungarian one ( 3 chambers in Slovakia). A ministry order was issued on January 20 1919. The Ministry of Industry, Commerce and Trades from January 20, 1919, no. 32, the Code of Laws and Orders according to which a so-called administration commissions were set up. In a temporary period untill 1922, they were assigned a number of tasks that would have been part of the state administration competence under normal circumstances - e.g. overcoming economic difficulties resulting from setting new border of the country. In 1922, the Central Office of Commerce and Trade Chambers was established and the structure was definitively specified.

${ }^{3}$ In the period literature its origin often used to be accompanied with the word 'at last' because the relationships of chambers to other businessmen, industrial and trade organizations were not clear and unnecessary disputes about competences often appeared. At the head of the Central Office there was a five-member presidium in which the biggest Commerce and Trade Chamber from Prague was represented by the post of the chairman, other chambers took turns in a certain order.
} 
take care of chambers unified representation at home and mainly abroad, and it should act as a certain organizer of common actions of all chambers. Among other issues, its work load also included publication activities. ${ }^{1}$

$\mathrm{CTCH}$ initiated the development of a number of institutes and institutions - e.g. the Institute for International Commerce at the Central Office, ${ }^{2}$ the Institute for Trades Improvements (1898), and the Institute for Supporting the Industry (1910). It is not only by chance that it was Prague's CTCH that initiated the organization of the General Provincial Jubilee Exhibition in Prague in 1891. In 1894 this Chamber also founded the Arts and Crafts Museum. In addition to it, the chambers looked after professional school system which they also financially subsidized. They helped Czech firms with their participation in trade fairs and exhibitions, they set up stockrooms of samples, cooperatives for purchasing of machines for miner tradesmen and the like. During the Occupation, the extent of activity, both of the Central Office and particular chambers was considerably curtailed. It was caused by the overall tendency of getting control over the economy in the Czech countries and its gradual swallowing up by the Reich concerns. After the liberation, the chambers were active until 1948. Their subsequent cancellation ended the almost one-hundred-year-long chapter of their existence.

\section{Trade Communities}

On the basis of provisions of relevant chapters of the Trade Code, trade communities existed as a little stone in the mosaic of administrative institutions, too. They were defined as protective and supporting organizations of traders. ${ }^{3}$ Communities joined together either one or more related branches - then it was an expert or mixed community. Communities of businessmen were called business committees. In one district and for the same category of trades, there could be only one community, and if a tradesman had more trades, he had to be a member of all communities established for those trades. Communities of the same political district, however, formed voluntarily District Associations of Trade Communities which then coordinated activities in the districts and supported their common interests and defended them at the relevant district authorities.

\footnotetext{
${ }^{1}$ In addition to special address books of Czechoslovak firms which were available on the occasion of exhibitions and trade fairs for international participants, a journal 'Chamber of Commerce' was published in Pilsen and 'Mitteilungen der Zentrale der Tschechoslowakischen Handels- und Gewerbekammern' (News from the Central Office of the Czechoslovak Commerce and Trade Chambers) in Liberec. Apart from that, the chambers published their own journals covering their sphere of activities, as e.g. CTCH Prague, 'News of the Commerce and Trade Chamber' quarterly in Prague, in German version it was then issued once a month.

2 This name was changed. In 1893 OŽK (CTCH) Prague established its export office that had to enlarge its agenda after the formation of Czechoslovakia, and in 1921 the Commerce Institute at $\mathrm{CTCH}$ Prague came into existence, which was later renamed as the institute for the support of foreign trade.

${ }^{3}$ According to the official text "the purpose of the community is to cultivate the spirit of sociability, to preserve and improve reputation of the profession as well as to encourage humanitarian, economic and educational interests of its members“. Chronicle of crafts, business, trades and production in the branch of CTCH in Olomouc. Olomouc 1942, p. 32.
} 
The most important task of the community was to keep decent relationships among its members, laborers and apprentices mainly in the field of employment and apprenticeship, sorting out of mutual disputes within the community, but also in relation to others (there are many examples, from serious disputes to rather curious ones - e.g. the dispute of bakers and confectioners over doughnuts, whether a baker can bake them, and if so, then whether he is allowed to sprinkle them with sugar etc.)

To found, support and supervise professional schools was another important task of the community, but also to build institutes for taking care of sick or impoverished members of communities and supervise them. Education and training of apprentices and organizing their finals was also the main goal of cooperation with chambers of commerce and trade (in 1943 that duty was taken over by Commerce and Trade Chambers). ${ }^{1}$

In 1939, the organization of communities was changed - according to the governmental directives about economic construction, industrial activities were organized compulsorily in the Central Union of Industry for Bohemia and Moravia, trades were then organized in the Central Union of Commerce for Bohemia and Moravia, while crafts were organized in the Central Union of Crafts. Further changes were materialized at the end of 1948. By the resolution of the Action Committee of the National Front, the Union of Czechoslovak Tradesmen became the only organization of all tradesmen; the activity of that union was naturally finished at the end of 1952.

\section{Trade Offices}

Trade offices were closely connected with firms in the branch of industry, commerce and trades as they directly granted and refused trade licenses. District and regional offices and the Ministry of Industry, Commerce and Trades also fulfilled their function but with graded competences. Within the Ministry of Social Welfare the Central Trade Inspectorate performed its activities and in a number of competences these activities overlapped with the Ministry of Industry, Commerce and Trades. ${ }^{2}$

For some political districts trade inspectors were appointed, who sought after firms to be controlled; then they kept an eye on the fulfillment of the Trade Office provisions, as well as of other laws. Affiliation to the Ministry of Social Welfare had predetermined which field was the most observed - it was especially the social position of employees, their work conditions, maintaining of public health measures and safety precautions. If workplaces were negatively evaluated and observing the rules was insufficient, it usually concerned small trades - especially in the periods of prosperity the rooms were overcrowded both by people and goods as businessmen used backed and quite unsuitable rooms. Inspectors also checked conditions of staircases, entrances, floors and exits, heating of workplaces, lighting, boiler rooms, steam vessels, driving gears and the like. Very consistently they also observed the condition of sanitary installations at

\footnotetext{
${ }^{1}$ More details in the inventory of the collection of Trade Communities in Ostrava 1874-1951, archives of the city of Ostrava.

${ }^{2}$ The collection of the Ministry of Social Welfare 1918-1951 is filed in the State Central Archives, Prague (The trade inspectorate was part of G MSP branch). Furthermore, it is the collection of the Ministry of Industry, Commerce and Trades 1919-1942 filed in the same archives.
} 
workplaces, cloakrooms, washrooms and canteens. From their reports it is obvious that the owners were interested in technical rationalization of production, its organization and in the overall state of technology in firms. ${ }^{1}$

Employment of workers and their protection were checked by inspections and, above all it concerned giving work to persons protected by the law and the conditions in which they worked (women, persons under 14 years of age etc.). Observing hours of work, time off, and e.g. respecting an interrupted rest at the length of 32 hours in some professions was also a part of inspectors' work load. Once a year trade inspectors gave a

\footnotetext{
${ }^{1}$ Offences against observing laws and regulations were branded as 'denouncement' in reports but actually it was a report on drawbacks. It mostly concerned small traders. A number of reports were rather curious, whichwas further emphasized by the curt 'official' language of reports worked out by inspectors. That is why I should like briefly to mention some of them:

E.g. in the area of hygiene:

Stock trading company Prague: "Some workers did not understand beneficial effects of fresh air on man's health and they clogged two ventilators by clothes and fenced them in. Ventilators were installed to exchange the air in large commercial rooms." (The State Central Archives of Prague, hereinafter SCA, collection of the Ministry of Labor - Trade Inspection - MSP ŽI, 1928. Prague I., card 3741);

Report on innkeepers trades worked out by the inspectorates in Brno mentioned: "Common sleeping of servants in beds, also apprentices did not have a bed of their own. Quite unsuitable rooms are used as bedrooms, for example bathrooms without a stove or cloth dryers...." (Firm owned by P. Fořt, Brno-Židenice restaurant, the SCA, collection of MSP ŽI, card 3742, 1928);

A firm of Ferdinand Majer, a baker in Strakonice, was criticized because his bakery was located in rooms without a natural lightning and airing, and to improve the air quality they even kept poultry and cooked feed for a pig. The Trade Office therefore suggested in its measures to perform a health and police inspection in all bakeries in the town. (SCA Prague, the collection of MSP ŽI, card 3741, 1928, Tábor);

Bakers had problems with inspectors because of not having permission for night work. To deliver baked goods to shops in time, a number of them started to work already 2 or 3 P.M. Night inspections took place with the police assistance. Sometimes it happened that bakers were accused of rough behavior and for the obstruction of official power (SCA Prague, collection of MSP ŽI, card 3758, 1933, Tábor). Hours of work were not observed in small trades such as tailors, shoemakers, dressmakers, milliners, in pubs, coffee houses and restaurants (SCA Prague, collection of MSP ŽI, card 3742, 1928, Brno).

A number of firms were punished for inappropriate behavior towards their staff and apprentices. Complaints often appeared that apprentices were at hand for entrepreneur's wife instead of being trained in the craft. Or, for example the firm of Václav Forejt, a tailor in Tábor: "Master tailor had a weird pretext for dismissing an apprentice who he engaged for the full pension; he dismissed him because he ate too much. After the intervention from the inspectorate the apprentice was taken back to work." (ibid, card 3776, 1936, Tábor);

Criminal proceeding against the firm of F. Hlaváček, cooperage, Opava: "Master cooper brutally treated his apprentices and beat them black and blue by dangerous tools such as a hammer and saw. He chose them from far ends, e.g. from the distant corners of Yugoslavia." (ibid, card 3742, 1928, Opava).

There were many such cases in reports. Probably the strangest report on apprentices' abuse appeared at the Trade Inspectorate Opava about the firm of J. Hamp, confectioner's shop: "Instead of training his apprentice in the craft, master confectioner made him busy with hypnotic productions to such extent that the apprentice fell ill. The Inspectorate intervened and deprived him of the right to have an apprentice." (SCA, MPS ŽI, card. 3761, Opava, 1933).
} 
report on the state of enterprise in particular areas of activities. ${ }^{1}$ On the basis of those reports, the Central Trade Inspectorate could form an idea of individual businesses and firms but also of overall economic trends of development. By reading them, we can also see the issues which are very topical at present - statements about mutual relationships among entrepreneurs as well as in the field of business ethics and entrepreneurs' relationships with their staff.

Observing Trade Law principles and other laws and directives connected with the development of enterprise in the sphere of industry, commerce and trade took place in several lines - both in the line of the state institutions - government, ministries, and in the line of interest organizations. Their competences overlapped in many cases, result of which was the support of enterprise, development of industrial sphere of skilled trades and business not only in Czechoslovakia but also abroad. To a certain degree, those administrative institutions can serve as an inspiration for the present time in which the code of rules for enterprise is being shaped and the viability of First Republic's organizations might be also confirmed.

\section{The Struggle against Unfair Competition}

The fact that the Trade Code did not limit the space for economic competition did not mean, however, that it did not make effort to specify mainly moral borders, rules of fair play. A number of bad experiences in business practice called for it and not only the Trade Code itself, but also other legal measures resulting from it developed a progressive initiative to that effect. One of the most significant laws was the law against unfair competition brought into effect in $1927,{ }^{2}$ which emphasized principles of truth, respectability and honesty in enterprise. For the current comparison, some passages are interesting - especially those concerning private protection and matters connected with economic competition as such. The unfair competition was insistently defined; data on quality and quantity of goods or performance, on purchasing sources, equity and credit conditions, on the way of production or setting the prices of goods, on manufacturing and business methods, on honors or permissions, personal circumstances, the length of existence or size of a business, on a stimuli, cause and the purpose of sales, performance or the amount of stock were in question. There was an interesting amendment to the $\S 2$ - piece of information was considered as publicly broken even if it was included in information for a wider range of persons, mainly at the labels on goods, on their covers, in public notices, business circulars, price lists and forms.

As for the incorrect label informing on the origin of goods the $\S 4$ suggested: "as an incorrect label of goods origin is understood every label capable to arouse an incorrect assumption in business connection that the good in question was made in a certain place or on the territory of a certain state.

\footnotetext{
${ }^{1}$ In reports, the overall characteristics of the area in which the inspector performed his duties were mentioned first and then the evaluation of the past year from the economic and social view. Fields and concrete firms were successful in their business activity were named, but also those that had to limit or even reduce their production.

${ }^{2}$ The Law No 111/1927 of the Code of Laws and the directive of Czechoslovakia of July 15, 1927.
} 
It does not depend on whether the incorrect labeling is on goods or on their immediate finishing or on their packaging or on containers, or whether it was used in announcements, labels, notices, business circulars, price lists, accounts, accompanying documents and so on. And it does not depend either, whether the incorrect labeling is used directly or indirectly, by words or images." These notes from 1927 seem to be quite appropriate in spite of certain clumsiness of the legal language. Also the misuse of corporate brands and outer device of the company was close to that paragraph. In that context it was emphasized that not only a direct and unjustly used name or logo of other firm but also causing a situation that could lead to confusion in the contact with a customer is punishable by that law. Paragraph 12 was laconically called 'bribery'. Not only the person who bribed but also the person who demanded it 'by the unfair practice to obtain advantages (in economic competition) for himself or for somebody else at the expense of other competitors' could be prosecuted. Further paragraphs dealt then with the violence and use of trade secrets and 'unfair competition of assisting persons and its use by a competitor', in other words it meant that without firm's knowledge, it was not possible for its employees to work for a competing firm.

Punishment for offenses against that law, such as unfair advertising, incorrect labeling of the origin of goods, and some other offenses including the punishment for not opposing crimes could last from 3 days to 1 month of imprisonment (in the law 'lock down' is mentioned); also penalties could be imposed, or both of them; punishments for offering a bribe with the aim to weaken other entrepreneurs, for the misuse of corporate brands and some other more serious offends were set in the length from 14 days to 6 months of imprisonment or a penalty up to $50,000 \mathrm{CZK}$, or as the case might be, combination of both punishments.

\section{Conclusion}

For the present, there are many facts in the economic past of the Czech lands that have been swept by time but which were very important for further development of this or that phenomenon. Every country has its own historical memory - there we can find more than mere circumstances that influenced the formation of traditions and processes based on experience for many decades. The rise of new capitalistic society in conditions of multinational Austro-Hungarian monarchy resulted in formation of new economic structures and new groups that brought about a number of changes. The rise of skilled trades, setting of legislation and institutions enabling further development of free enterprise in the intentions of codes and laws - this is a chapter of the Czech economic history which still has not been described sufficiently. However, it resulted in the fact that further development not only in independent and democratic Czechoslovakia but also further systems connected with wartime controlled economy, as well as with a postwar socialistic period, were returning to its roots. 


\section{References}

BROM, B. (2001). Historie obchodních a živnostenských komor na území českých zemí (od počátki̊ až po jejich zrušení) (1850 - 1948). Praha. Retrieved from www.komora.cz/download.aspx?dontparse=true \&FileID $=144$.

GERŠLOVÁ, J., SEKANINA, M. (2003). Encyclopedia of the Czech Economic History of the 19th and the 20th Century in the Political and Social Circumstances. Prague: Libri.

JAKUBEC, I. (2007a). Vytváření obchodnických elit se zvláštním zřetelem k pražské obchodní a živnostenské komoře. In ŠTAIF, Jiří Štaif (ed.), Moderní podnikatelské elity - metody a perspektivy bádání. Praha: Dokořán, s. 111-127. ISBN 978-80-7363-153-6.

JAKUBEC, I. (2007b) Projevy (hospodářského) nacionalismu v pražské obchodní a živnostenské komoře ve druhé polovinè 19. století. In HÁJEK, J., JANČÍK, D., KUBÜ, E. (eds.). O hospodářskou národní državu. Úvahy a stati o moderním českém a německém nacionalismu $v$ českých zemích. AUC, Philosophica et Historica 1-2005, Studia historica LIX, Praha 2009, s. 179-188. ISBN 978-80-246-1391-8. ISSN 05678293.

JAKUBEC, I. (2007/2008). Bildung der Handelseliten am Beispiel der Prager Handelsund Gewerbekammer. In: Prager wirtschafts- und sozialhistorische Mitteilungen/Prague economic and social history papers, vol.8, s. 21-31. ISBN 978-807308-232-1.

JAKUBEC, I. (2008). Znamená obnova tržní ekonomiky návrat $k$ institucím éry rakouského liberalismu? Pokus o srovnání obchodních a živnostenských komor a Hospodářské komory České republiky. In 19. století v nás. Modely, instituce a reprezentace, které přetrvaly. Praha: Nakladatelství historický ústav. Moderní dějiny Suplementum 1 (2008), s. 342-354. ISBN 978-80-7286-139-2. ISSN 1210-6860.

ROUČEK, F. (1938). Czechoslovak Business Law. 1., general part, p. 43 an.

WEYER, F. (1926). Chamber of Commerce journal, No. 12, p. 1-7.

The Dictionary of Czechoslovak Public Law, Volume IV, Brno 1938

The chronicle of crafts, business, trades and production in the branch of CTCH in Olomouc. Olomouc 1942, p. 32

The State Central Archives of Prague, collection of the Ministry of Labor - Trade Inspection - MSP ŽI, 1928. Prague I., card 3741

The State Central Archives of Prague, the collection of MSP ŽI, card 3741, 1928, Tábor The State Central Archives of Prague, collection of MSP ŽI, card 3758, 1933, Tábor

The Law No 111/1927 of the Code of Laws and the directive of Czechoslovakia of 15. July 1927 